\title{
PENINGKATAN KOMPETENSI COACH DALAM PROGRAM PENDAMPINGAN EKSPOR DI ERA DISRUPTIF TEKNOLOGI
}

\author{
Abdillah Sani ${ }^{1)}$ \\ Widyaiswara Kementerian Perdagangan/ \\ Fakultas Ekonomi dan Bisnis \\ Universitas Islam Syekh Yusuf Tangerang \\ asani@unis.ac.id \\ Mohammad Husyain HMS $^{2)}$ \\ Fakultas Ekonomi dan Bisnis \\ Universitas Islam Syekh Yusuf Tangerang \\ mohammad.husyain@unis.ac.id
}

\section{DOI: https://doi.org/10.33592/jeb.v26i1.617}

\section{ABSTRAK}

Usaha Kecil dan Menengah (UKM) Indonesia yang tersebar di berbagai daerah dan kota besar, banyak yang memiliki produk yang potensial untuk diekspor, sehingga tidak aneh jika banyak buyer yang secara langsung rela mendatangi sentra-sentra produk yang ada di Indonesia dalam rangka menemukan produk untuk dijual di pasar di Negara mereka. Pemerintah juga telah menyelenggarakan berbagai kegiatan dan pemberian fasilitasi agar para UKM potensial mampu menjadi eksportir pendatang baru. Program Pendampingan Ekspor (Export Coaching Program) adalah pendampingan bagi UKM potensial ekspor selama satu tahun penuh yang sudah dilakukan sejak tahun 2010 oleh Kementerian Perdagangan, sebanyak 3 angkatan untuk 3 daerah dan masing-masing dikuti oleh 25 orang peserta. Namun demikian, program ternyata masih belum mampu membuahkan hasil sebagaimana yang diharapkan, karena UKM yang berhasil menjadi eksportir baru belum mencapai separuh dari jumlah peserta. Banyak hal menjadi penyebab, antara lain adalah kurang maksimalnya proses seleksi calon peserta, monitoring harian perkembangan peserta dan kurang optimalnya konsultasi peserta atas masalah-masalah yang mereka jumpai kepada para Coach (pendamping) yang ditunjuk. Tulisan ini mencoba menjelaskan pelaksanaan Program Pendampingan Ekspor, kendala-kendala yang dihadapi serta hasil akhir yang dicapai sejak tahun 2010 sampai dengan 2018.

Kata Kunci : Coach, Ekspor, Program Pendampingan, Kompetensi, Disruptif Technologi

\begin{abstract}
Small and Medium Enterprises (SMEs) of Indonesia, which are spread in various regions and big cities, many have potential products for export, so it is not strange if many buyers are directly willing to visit the product centers in Indonesia in order to find products for sold in markets in their countries. The government has also held various activities and facilitation so that potential SMEs are able to become new exporters. The Export Coaching Program is an assistance for potential export SMEs for a full year that has been carried out since 2010 by the Ministry of Trade, with 3 batches for 3 regions and 25 participants each. However, the program turned out to still not be able to produce the results as expected, because SMEs that have succeeded in becoming new exporters have not reached half the number of participants. Many things cause, among others, the lack of a maximum selection process of prospective participants, daily monitoring of participant development and the lack of optimal consultation of participants on the problems they encounter with the appointed Coach. This paper tries to explain the implementation of the Export Assistance Program. the constraints faced and the final results
\end{abstract}




\section{A. Pendahuluan}

Globalisasi komunikasi telah membawa perubahan dalam aktivitas bisnis para usahawan kecil dan menengah (UKM) di Indonesia, yang memiliki potensi untuk memasuki pasar dunia dan menjual produknya ke berbagai Negara. Perkembangan teknologi ini juga mendorong terjadinya perubahan dalam tatanan kerja UKM, karena persaingan bisnis modern saat ini membutuhkan SDM yang menguasai teknologi dan informasi. Perkembangan teknologi informasi membuka peluang kerjasama dan jejaring bisnis yang dibutuhkan antar UKM untuk saling mendorong dan menopang kemajuan satu sama lain.

Dalam era kemajuan teknologi seperti ini, pengaruh perkembangan teknologi telah mempengaruhi semua aspek dalam bisnis seperti pertukaran informasi, pola-pola pemasaran yang dijalankan, sistem perdagangan yang terbentuk, produk-produk yang dihasilkan, harus memberi pengaruh terhadap tingat kemampuan SDM semua pihak yang terkait, baik itu pemerintah, pelaku bisnis, para investor, investor, perbankan maupun tenaga pengajar di kalangan akademik maupun lembagalembaga diklat Pemerintah. Secara simultan semua pihak memang harus mampu mengubah mindset dalam mengantisipasi perubahan iklim bisnis.

Dalam era digital, persaingan bisnis tidak bisa lagi hanya dipandang dan dihadapi dengan cara lama, karena paradigma persaingan bisnis saat ini sudah banyak mengalami pergeseran dari paradigma kompetisi menjadi paradigma kemitraan, bahkan peranan Pemerintah yang semula merupakan regulator, kini harus berubah menjadi fasilitator dan pendamping (coach), agar mampu rangka mendongkrak pertumbuhan bisnis, baik di tingkat lokal, maupun di tingkat dunia.

Keharusan sama juga berlaku bagi Balai Besar Pendidikan dan Pelatihan Ekspor Indonesia (PPEI) yang dibentuk oleh Pemerintah Indonesia bekerjasama dengan JICA Jepang pada tahun 1990 dan sampai saat ini masih terus aktif menjalankan aktivitasnya membina dunia usaha ekspor melalui kegiatan-kegiatan pelatihan. PPEI yang merupakan unit organisasi setingkat eselon II di bawah Direktorat Jenderal Pengembangan Ekspor Nasional- Kementerian Perdagangan, mempunyai tugas pokok dan fungsi untuk melakukan pembinaan dan pemberdayaan para UKM di bidang ekspor dan impor melalui penyelenggaraan kegiatan pelatihan-pelatihan. PPEI harus mampu menyesuaikan diri dengan era teknologi, melalui pelatihan-pelatihan yang secara rutin diselenggarakan sebanyak kurang lebih 130 an angkatan per tahun, untuk wilayah DKI Jakarta dan berbagai daerah di Indonesia. Peserta yang setiap angkatannya berjumlah 30 orang harus mendapat pelatihan ekspor berbasis teknologi. Jlka tidak, maka pelatihan-pelatihan tersebut akan ketinggalan jaman dan tidak mampu membawa pelaku ekspor memenangkan persaingan di kancah global.

Mengingat banyaknya topik pelatihan yang diselenggarakan oleh PPEI, tulisan ini memfokuskan perhatian terhadap salah satu jenis kegiatan yang dianggap memiliki pengaruh terhadap upaya penciptaan eksportir baru, yakni Program Pendampingan Ekspor (Export Coaching Program). Program ini merupakan pembinaan terpadu selama satu tahun anggaran bagi UKM yang memiliki produk potensial untuk dikembangkan menjadi produk ekspor. Sejak tahun 2010 program ini telah dijalankan di berbagai propinsi dan kota-kota besar di Indonesia, antara lain Jakarta, Bandung, Surabaya, Solo, Banjarmasin, Makassar, Lombok, dan lainlain. Setiap satu tahun, program ini diselenggarakan sebanyak 3 (tiga) angkatan di 3 (tiga) daerah berbeda untuk 25 orang UKM. Pada tahun 2018, program Pendampingan Ekspor ini dilaksanakan di Tangerang, Surabaya dan Bandung sedangkan dalam tahun anggaran 2019 kegiatan ini diselenggarakan di Jakarta, Bandung dan Semarang dengan jumlah peserta masing-masing angkatan adalah 25 orang per daerah.

Untuk mendapatkan sebanyak 25 orang peserta program tersebut, dilakukan seleksi berlapis, bekerja sama dengan lembaga/ 
organisasi setempat, misalnya dengan Pusat Pelatihan dan Promosi Ekspor Daerah (P3ED) di Surabaya, Banjarmasin, Makassar, Nusa Tengara Barat, atau dengan Universitas seperti di Solo, Pekalongan, dan Yogyakarta. Kerjasma juga biasa dilakukan dengan menggandeng Dinas Perindustrian dan Perdagangan setempat, seperti di Semarang, Bandung dan Tangerang, maupun KADIN setempat.

Meskipun proses seleksi telah dilaksanakan, ternyata masih banyak UKM peserta program ini (terutama di daerah), yang memiliki banyak keterbatasan, baik dalam pengetahuan maupun penggunaan teknologi internet di dalam bisnisnya, yang berakibat produk maupun SDM nya masih perlu ditingkatkan agar mampu memenuhi kebutuhan pasar internasional. Hal ini memberi pengaruh saat UKM melakukan pemasaran (international marketing), karena apa yang dilakukan umumnya masih konvensional dan belum berdasarkan strategi promosi berbasis tekonologi digital.

Adapun hasil yang telah dicapai dalam pelaksanaan Program Pendampingan Ekspor selama 5 tahun terakhir adalah sebagaimana terlihat dalam tabel berikut:

\section{Tabel 1}

Dari tabel 1 terlihat bahwa dalam pelaksanaan Program Pendampingan Ekspor sejak tahun 2010 sampai dengan tahun 2018, hasil akhir yang dicapai masih belum optimal jika dibandingkan dengan banyaknya jumlah peserta, meskipun target eksportir baru yang ditetapkan dapat dicapai.

Dalam kegiatan pendampingan ekspor, Widyaiswara merupakan tenaga fungsional yang memiliki tugas pokok untuk mengajar, melatih, melaksanakan konsultasi dan mendampingi para peserta dalam kegiatankegiatan pelatihan. Kendala-kendala yang dialami oleh para UKM sebagaimana disebutkan di atas, akan berkorelasi langsung dengan tugas para Widyaiswara. Modernisasi strategi Pembinaan dan Peningkatan kemampuan Widyaiswara untuk membina UKM potensial harus sejalan dengan upaya mengatasi kendala disruptif teknologi. Dalam kaitan ini, Penulis memfokuskan pembahasan terhadap permasalahan pelaksanaan tugas

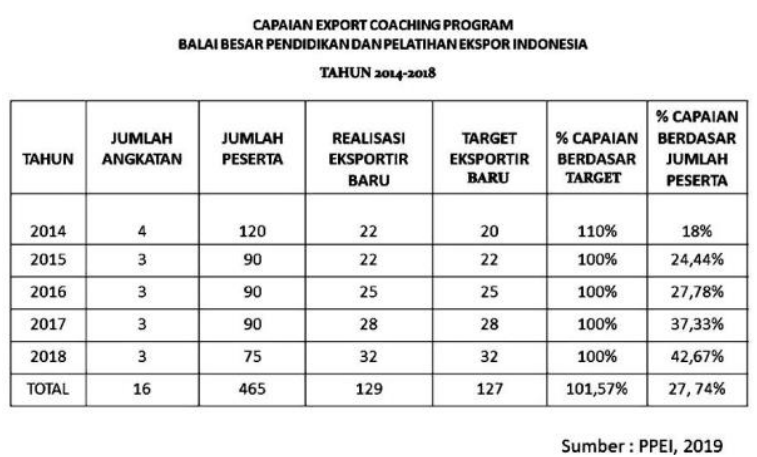

para Widyaiswata sebagai Coach dalam Program Pendampingan Ekspor.

Program Pendampingan Ekspor menerapkan metode pendampingan selama satu tahun penuh. Metode coaching dipilih karena dianggap lebih ampuh daripada metode pelatihan konvensional di kelas, seperti dijelaskan oleh Rosinsky (2013, dalam Norasmah Othman dan Swee Yee Chia, 2014), bahwa Coaching adalah poses mengasah keterampilan dan membantu orang lain dalam melepaskan potensi mereka guna mencapai tujuan yang diinginkan. Sir John Whitmore (2009), juga menyebutkan bahwa Coaching membuka potensi seseorang untuk memaksimalkan kinerja mereka sendiri dan lebih membantu mereka belajar daripada mengajar mereka, karena dalam coaching, terjadi serangkaian dialog antara Coach dan peserta pelatihan (Starr, 2008).

Coaching mengacu pada proses sistematis untuk meningkatkan kinerja seseorang dalam proses belajar mengajar dengan cara memberi panduan dan umpan balik (Redshaw, 2000). Coaching juga memungkinkan individu untuk memperoleh pengetahuan dan keterampilan yang mereka butuhkan untuk mengembangkan praktek profesional dan bekerja lebih efektif (Stone, 1999). Penggunaan metode coaching merupakan arahan dari Trade Fascilitation Ofiice, Canada (2010) sebagai mitra kerjasama PPEI dalam Program Pendampingan Ekspor yang menyebutkan bahwa program tersebut memiliki 3 tahap sasaran yang ingin dicapai, yakni: "The three stages of export preparation help the exporter to learn about exporting step-bystep. The exporter can focus on each step until they have accomplished the objectives for that stage." 
Banyak model bisa digunakan dalam Coaching, beberapa diantaranya adalah model transpersonal, cultural transformational tool, kurva perubahan, analisa transaksional, dan model appreciative inquiry (Berny Gomulya, dkk, 2019), namun model coaching yang dianggap sesuai untuk Program Pendampingan Ekspor adalah model GROW. GROW menurut Berny Gomulya (2015) adalah singkatan dari Goal (tujuan), Reality (kenyataan), Options (pilihan) dan What Next atau Will (harapan), yang struktur dasarnya pertama kali dikemukakan oleh Sir John Whitemore. Ide dasar model GROW ini memiliki kesesuaian dengan tujuan penyelenggaraan Program Pendampingan Ekspor oleh PPEI, yakni mendorong lahirnya eksportir baru berdasarkan kondisi nyata yang ada pada setiap UKM peserta, Model Coaching dianggap paling sesuai untuk membina UKM ekspor, karena dapat lebih meningkatkan motivasi, pengambilan keputusan, hubungan antar peserta dan antara peserta dengan coach.

Pemilihan coaching sebagai model pembinaan UKM sesuai dengan hasil sebuah survei yang dilakukan oleh Chartered Institute of Personel and Development, yang menemukan bahwa 99\% dari 500 responden setuju bahwa 'Coaching dapat menghasilkan manfaat nyata, baik bagi individu maupun organisasi. Hasil survey itu juga menunjukkan bahwa 96\% responden setuju bahwa Coaching adalah cara yang efektif. untuk mempromosikan pembelajaran di organisasi (NHS, 2005, dalam Norasmah Othman1 dan Swee Yee Chia, 2014).

\section{B. Metode Penelitian}

Penelitian ini merupakan penelitian deskriptif yang datanya didapat dari data sekunder, yakni data-data yang ada pada balai Besar Pendidikan dan Pelatihan Ekspor Indonesia-Kementerian Perdagangan, observasi dan pengalaman Penulis sebagai salah satu Coach dalam program tersbeut dan sumber-sumber lain yang relevan. Sebelum dilakukan pembahasan lebih jauh, beberapa definisi harus dikemukakan terlebih dahulu untuk menyamakan pemahaman atas berbagai istilah yang digunakan dalam tulisan ini. Beberapa diantaranya yang kerap digunakan adalah sebagai berikut:

- Program Pendampingan Ekspor (Export Coaching Program)

Merupakan program yang dilaksanakan oleh Balai Besar Pendidikan dan Pelatihan Ekspor Indonesia (PPEI), Direktorat Jenderal Pengembangan Ekspor Nasional (DJPEN), Kementerian Perdagangan, yang ditujukan bagi para UKM yang memiliki potensi untuk dikembangkan menjadi eksportir. Program Pendampingan ini memiliki 3 tujuan utama yakni mempersiapkan peserta pada :

Stage I : Export Preparation, yakni membedah potensi yang dimiliki UKM peserta dan membenahi kekurangankekurangan yang ada, melengkapi persyaratan yang dibutuhkan dalam rangkan ekspor, membuat analisis SWOT, menyusun action plan dan membuat rencana bisnis (business plan);

Stage II : Market Development, yakni memberikan arahan kepada peserta agar memiliki pengetahuan tentang pasar ekspor, bagaimana menelusuri informasiinformasi yang dibutuhkan dan melakukan tindakan-tindakan adaptasi sesuai tuntutan pasar, baik yang menyangkut produk maupun hal lainnya

> Stage III : Entering the Market, yakni membimbing dan mengajarkan peserta bagaimana menyusun strategi pemasaran dan melakukan persiapan lanjutan dalam rangka realisasasi ekspor seperti melakukan export costing and pricing, melakukan export correspondence, menyusun export sale contract, export procedures, dan lain-lain.

Ketiga tahapan tersebut terlihat dalam gambar berikut:

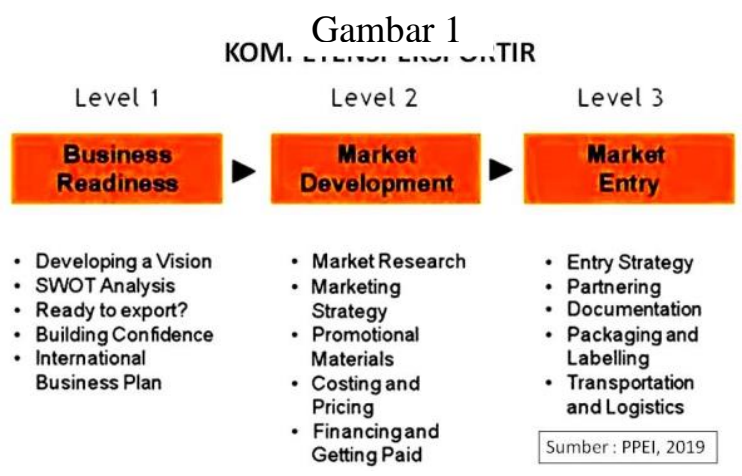


Dalam pelaksanaan Program Pendampingan Ekspor terdapat dua jenis pengajar atau fasilitator, yakni para pengajar internal PPEI yang merupakan pejabat fungsional Widyaiswara dan para pengajar eksternal PPEI yang direkrut dari kalangan praktisi ekspor, sedangkan Widyaiswara adalah Pegawai Negeri Sipil (PNS) pada lembaga pendidikan dan pelatihan (diklat) pemerintah yang dalam Program Pendampingan Ekspor (Export Coaching Program) merupakan Pendamping (Coach) bagi para peserta. Para pendamping lain berasal dari praktisi ekspor yang menjadi instruktur PPEI juga merupakan fasilitator yang dibutuhkan bimbingannya berdasarkan pengalaman praktek menjalani bisnis ekspor.

Disruptive Technology adalah dampak dari inovasi teknologi yang membuat suatu proses yang sudah ada menjadi terganggu, dalam artian eksistensinya terancam karena adanya teknologi yang baru tersebut. Beberapa contoh disruptive technology adalah.

$>$ penemuan baru yang belum pernah ada sebelumnya, sedangkan yang kedua adalah disruptive technology yang mengisi kekosongan karena tidak terakomodasi oleh teknologi yang sudah ada.

$>$ E-mail, surat elektronik, merupakan disruptive techylogy untuk direct post (surat biasa)

$>$ Komputer, adalah disruptive technology bagi mesin ketik

> Kamera digital adalah disruptive technology bagi kamera biasa yang memakai film.

> SMS (Short Messaging Services) adalah disruptive technology bagi pager.

> PDA/XDA adalah disruptive technology bagi Laptop/PC

Dalam konteks Program Pendampingan Ekspor yang dibahas dalam tulisan ini, seorang Coach diharapkan mampu memberikan arahan dan bimbingan terhadap peserta, dalam hal disruptive technology yang menyangkut:

$\checkmark$ Pemanfaatan mesin pencarian informasi (search Engine) pada internet seperti Google, Alibaba, dan lain, guna mengetahui perkembangan pasar, trend pasar, potensi pasar, Negara tujuan ekspor potensial, selera pembeli, dan sebagainya;

$\checkmark$ Pemanfaatan internet untuk melakukan pemasaran produk ke pasar internasional, seperti penggunaan website, email dan promosi, seperti melalui Google, Youtube, Facebook, Instagram, Blog, WhatsApp dan sebagainya;

$\checkmark$ Menjalin komunikasi antara para peserta dengan para calon pembeli (buyers) di luar negeri, baik secara langsung, melalui teleconference dalam business matching, melalui misi dagang (trade mission), temu bisnis (business meeting), maupun melalui peranan para Atase Perdagangan dan Indonesia Trade Promotion Center (ITPC) di berbagai Negara.

Ada 2 faktor yang memengaruhi UMKM dalam mengadopsi TI menurut Ghobakhloo dkk. (2011) ${ }^{3)}$ yaitu faktor internal dan eksternal. Faktor internal terdiri atas keputusan dari pelaku UMKM (top management), ada modal atau anggaran untuk pengembangan TI, sumber daya manusia bidang TI yang ada di UMKM, adanya aplikasi TI yang sesuai dengan kebutuhan dan budaya/ kareteristik UMKM itu sendiri. Sedangkan faktor eksternal adalah faktor-faktor yang memengaruhi, seperti lingkungan yang kompetitif (persaingan dengan UMKM lain), peranan pemerintah, pelangggan dan supplier, serta konsultan TI dan vendor.

Program Pendampingan Ekspor sejak tahun 2010 sampai saat ini telah dilakukan oleh PPEI di berbagai daerah, masing-masing sebanyak 3 angkatan per tahun untuk 3 daerah, seperti di:

- Jakarta

- Semarang

- Bandung

- Makassar

- Banjarmasin

- Surabaya

- Solo

- Yogyakarta

- Pekalongan

- Tangerang

Daerah-daerah tertentu, sesuai dengan kebutuhan dan banyaknya jumlah UKM 
potensial telah menyelenggarakan beberapa angkatan, seperti Jawa Barat yang telah melaksanakan sebanyak 6 (enam) angkatan, dengan pola kerjasama kontraktual antara Dinas Perindustrian dan Perdagangan Propinsi Jawa Barat dengan PPEI. Sedangkan untuk wlayah DKI Jakarta, sampai dengan tahun 2018 setiap tahunnya terlaksana program pendampingan ekspor, mengingat sebagai ibukota negara dan pusat bisnis, Jakarta memiliki banyak UKM yang potensial untuk menjadi eksportir.

Pada hampir semua daerah di atas, termasuk Jakarta sendiri, ternyata penguasaan TI oleh UKM peserta masih belum memadai dalam artian mereka masih belum sepenuhnya memanfaatkan TI sebagai faktor penunjang yang sangat penting dalam kegiatan bisnis, hal mana dibuktikan dengan:

- Banyak peserta yang belum memiliki website, log, media sosial $(F B, I G$, Youtube link)

- Beberapa diantaranya bahkan belum punya akun email

- Belum mengetahui bagaimana memanfaatkan search engine untuk menggali informasi, baik informasi pasar, produk, trend, dan sebagainya

- Belum mengetahui apalagi melakukan market research menggunakan internet

- Belum mengetahui bagaimana menggunakan internet sebagai sarana promosi

- Belum memanfaatkan internet untuk mencari informasi dan ide-ide kreatif inovatif untuk produk maupun pengembangan perusahaan mereka

- Belum pernah mengontak perwakilan dagang Indonesia seperti Atase Perdagagan maupun Indonesia Trade Promotion Center (ITPC) dalam rangka mencari informasi pasar

- Belum memiliki kemampuan berbahasa Inggris yang memadai

- Belum memiliki gambaran tentang negara yang akan menjadi tujuan ekspor karena jarang membuka internet

- Belum punya gambaran tentang calon pembeli luar negeri yang potensial, beriktikad baik serta trend maupun selera pembelian mereka.

Mengingat hal-hal di atas, maka peranan seorang Coach menjadi sangat strategis dalam meningkatkan kesiapan maupun kemampuan para UKM peserta program pendampingan.

Peran Coach dalam meningkatkan kemampuan peserta di bidang TI adalah sebagai berikut:

1) Meningkatnya pengetahuan mengenai TI dan search engine sebagai sumber informasi dan sarana melakukan penelitian pasar

2) Meningkatnya pemahaman mengenai TI sebagai alat pemasaran dan jenis promosi lain ke pasar internasional

3) Terciptanya kemampuan memanfaatkan TI sebagai alat komunikasi langsung antara mereka dengan para calon pembeli di Negara tujuan ekspor dalam rangka realisasi ekspor

4) Meningkatnya pemahaman dalam memanfaatkan TI sebagai alat pembayaran internasional,

5) dan lain-lain hal yang terkait dengan pemanfaatan TI untuk menunjang bisnis

Selain sasaran-sasaran di atas, seorang Coach juga harus mampu mengubah mindset dan mentalitas para peserta program pendampingan, serta mendorong mereka agar terus berfikir kritis dalam menghadapi perubahan kondisi bisnis yang semakin kompetitif. Perubahan mindset dan mental ini sangat penting dalam melaksanakan bisnis ekspor, karena jika para pelaku usaha tidak siap dan tidak mampu menghadapi kondisi era disruptive technology sekarang ini, bukan saja berbagai dampak dapat timbul dan mempengaruhi kelangsungan bisnis mereka, tapi hal itu juga akan membuat mereka tidak bisa mengembangkan usahanya ke tingkat yang lebih luas.

Dalam penelitian tentang pelaksanaan program peningkatan peranan Coach dalam Program Pendampingan Ekspor PPEI ini, bahan-bahan yang digunakan sebagai acuan adalah sebagai berikut:

Standard Operational Procedures (SOP) yang mengatur tata kerja dan memberi arahan tentang mekanisme yang harus ditempuh oleh Coach. Tanpa SOP ini, pelaksanaan kerja Coach akan overlapping dengan tugas dari Ketua 
Panitia Pelaksana (Course Leader). Course Leader berfungsi manajerial tata kelola program selama satu tahun pelaksanaan, sedangkan Coach berfungsi ke arah penguasaan substansi ekspor oleh peserta dalam proses pendampingan, sampai akhirnya mereka mampu merealisasi ekspor.

$\checkmark$ Informasi tentang Negara tujuan ekspor dan daftar pembeli (buyer list) yang actual dan akurat dari berbagai sumber, terutama dari perwakilan dagang Indonesia di luar negeri seperti Atase Perdagangan dan Indonesia Trade Promotion Center (ITPC) yang memang memiliki tugas pokok dan fungsi utama menyediakan informasi-informasi seperti ini.

$\checkmark$ Surat Edaran yang ditandatangani oleh Menteri Perdagangan, atau paling tidak oleh Direktur Jenderal Pengembangan Ekspor Nasional, agar para Atdag maupun ITPC menyediakan bahan-bahan informasi yang dibutuhkan secara actual dan akurat, dimana para Atdag maupun ITPC itu selalu melakukan updating terhadap informasi tersebut, sehingga tidak kadaluwarsa atau out off date. Tanpa adanya Surat Edaran dari pimpinan seperti ini, Atdag maupun ITPC akan mudah mengabaikan permintaan data, bukan hanya dari Coach yang notabene merupakan pejabat fungsional di lingkungan Kementerian Perdagangan, apalagi email-email yang dikirimkan oleh pelaku usaha.

$\checkmark$ Business Plan atau Rencana Bisnis yang harus dibuat oleh para peserta sebagai patokan bersama antara peserta dan Coach tentang tahapan-tahapan yang harus dilaksanakan peserta selama menjalani program pendampingan. Peserta sejak awal sudah harus membuat rencana bisnis ini, sehingga tiga tahapan yang harus dilalui dalam program pendampingan, yakni Business Prepation, Market Development dan Market Entry, sebagaimana telah dikemukakan di depan, dapat dietelusur dengan baik oleh Coach dan Peserta.

$\checkmark$ Formulir Progress Report atau laporan perkembangan kemajuan, yang akan mencatat setiap perkembangan yang terjadi, termasuk kemajuan yang telah dicapai peserta, tahap demi tahap, sejak awal pembukaan program pendampingan hngga program ini dinyatakan telah selesai dan ditutup.

$\checkmark$ Dokumen-dokumen bukti realisasi ekspor yang harus diserahkan oleh peserta, sebagai dasar dilakukannya pengelompokan (grading) atas hasil capaian peserta selama mengikuti program pendampingan ini. Pada akhir program pendampingan, peserta akan dikelompokkan menjadi tiga grade, yakni:

- Grade A, yakni peserta yang telah mampu merealisasi ekspor

- Grade B, yakni peserta yang sudah mendapatkan calon pembeli namun prosesnya masih berjalan sehingga belum tercapai realisasi ekspor

- Grade C, yakni peserta yang belum menunjukkan perubahan signifikan menjadi calon eksportir, atau mereka yang tidak secara disiplin mengikuti tahapan-tahapan dalam program pendampingan ini.

Adapun hasil grading peserta Program Pendampingan Ekspor pada tahun 2018 adalah sebagai berikut:

Tabel 2

\begin{tabular}{|l|c|c|c|c|}
\multicolumn{5}{c}{$\begin{array}{c}\text { Grading Peserta Program Pendampingan Ekspor } \\
\text { berdasarkan Evaluasi Akhir tahun 2018 }\end{array}$} \\
\begin{tabular}{|l|c|c|c|c|}
\hline & $\begin{array}{c}\text { Kabupaten } \\
\text { Tangerang }\end{array}$ & Surabaya & Bandung & Jumlah \\
\hline Grade A & 5 & 12 & 14 & 32 \\
\hline Grade B & 10 & 9 & 10 & 18 \\
\hline Grade C & 10 & 4 & 1 & 25 \\
\hline Jumlah & 25 & 25 & 25 & 75 \\
\hline
\end{tabular}
\end{tabular}

\section{Hasil dan Pembahasan}

Dalam pelaksaan Program Pendampingan Ekspor, diketahui bahwa seorang Coach memiliki tahapan kerja sebagai berikut:

1) Coach bersama-sama dengan Course Leader, manajamen PPEI dan mitra kerja program pendampingan ekspor, melakukan seleksi calon peserta yang memenuhi kriteria sesuai ketentuan. Pengumpulan calon peserta biasanya dilakukan melalui kegiatan workshop 
berupa sosialisasi program ini, dengan mengundang 50 orang UKM yang dianggap potensial. Keseluruhan peserta ini akan diverifikasi dengan cara peninjauan langsung ke lokasi perusahaan mereka, untuk mengecek akurasi dan aktualitas data yang mereka masukkan kepada Panitia. Dari 50 orang calon peserta, akan dipilih 25 orang yang memenuhi syarat sebagai peserta.

2) Coach memberikan arahan dalam hal pebuatan analisis SWOT dan Rencana Bisnis bagi setiap Peserta, serta menekankan bahwa Business Plan ini adalah pedoman bersama antara peserta dengan Panitia dalam memantau perkembangan kemajuan peserta dalam mengikuti tahapan-tahapan Program Pendampingan.

3) Coach bersama-sama dengan instruktur praktisi PPEI akan menilai dan memberi arahan kepada peserta dalam presentasi business plan mereka. Pada saat ini presentasi ini Coach mengarahkan agar peserta menetapkan dalam business plan mereka ke pasar di Negara mana rencana bisnis mereka akan ditujukan. Dengan demikian setiap peserta akan menyusun Business Plan yang judulnya adalah: "RENCANA BISNIS EKSPOR PRODUK $X$ KE NEGARA Y PADA TAHUN Z."

4) Coach akan menyebarkan buyer list atau daftar calon pembeli yang dikirimkan oleh Atase Perdagangan dan IPTC sesuai Surat Edaran dari Pimpinan Kemendag. Peserta akan melakukan penelusuran ke alamatalamat dalam daftar tersebut untuk mengecek validitas data alamat yang diberikan dan selanjutnya mengirim surat perkenalan (introduction letter) kepada calon pembeli.

5) Jika surat perkenalan yang dikirimkan peserta mendapat sambutan balasan dari calon pembeli berupa inquiry, maka Coach akan mengontak Atase atau ITPC dari negara mana buyer itu berasal, agar Atdag maupun ITPC terkait tersebut ikut membantu memantau perkembangan yang terjadi dalam komunikasi antara peserta dengan calon pembeli tersebut. Atase atau ITPC selanjutnya akan membantu mengarahkan agar peserta dan calon pembeli bisa melakukan video call melalui skype yang dipandu oleh Coach. Kedua belah pihak diharapkan membicarakan lebih jauh tentang rencana ekspor yang akan dilakukan, terutama yang menyangkut persyaratan yang harus dipenuhi.

6) Coach dan Atase Perdagangan atau ITPC mendorong dan mengusahakan agar kedua belah pihak, yakni peserta dan calon pembeli dapat bertemu secara langsung dalam Trade Expo Indonesia yang dilaksanakan di Jakarta setiap tahun, biasanya pada bulan Oktober, untuk membicarakan lebih detail rencana realisasi ekspor dan menyusun bersama suatu kontrak dagang.

7) Coach akan terus memantau perkembangan yang terjadi dan siap memberikan konsutasi kepada para peserta, baik yang menyangkut materi ekspor yang merupakan kompetensinya sendiri, maupun menghubungi Coach lain jika materi yang ingin dikonsultasikan oleh peserta bukan merupakan kompetensinya.

8) Berdasarkan data perkembangan kemajuan peserta yang dipegangnya dan juga data dokumen realisasi ekspor yang dikirimkan oleh peserta, Coach akan menyusun draft grading peserta menjadi 3 kelompok, yakni Grade A, B dan C. Draft ini selanjutkan akan diajukan dan dibahas dalam rapat evaluasi bersama-sama dengan Course Leader, manajemen PPEI dan pihak mitra kerja, untuk menentukan finalisasi grading peserta

Gambar 2.

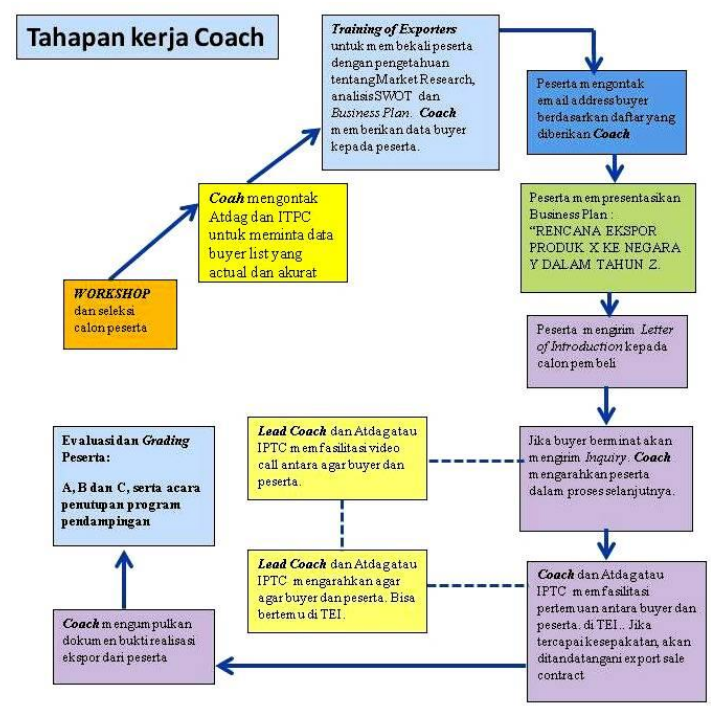


Berdasarkan gambar di atas, menjadi jelas bahwa sejak awal pelaksanaan Coaching Program, seorang Coach akan mengarahkan agar semua peserta menjalani proses "learning by Doing”, yakni secara langsung akan melakukan korespondensi dengan para calon pembeli di luar negeri, dimana hal tersebut akan dituangkan ke dalam Rencana Bisnis (Business Plan) mereka ke Negara Tujuan Ekspor produk masing-masing, sehingga Rencana Bisnis yang mereka buat akan lebih terarah dan memiliki prospek tercapainya realisasi ekspor di akhir pelaksanaan Coaching Program.

Dalam penulisan ini, instrument yang digunakan untuk mengukur tingkat keberhasilan pelaksanaan peran Coach antara lain adalah:

1) Analisis SWOT untuk mengetahui kondisi kesiapan para UKM peserta program pendampingan ekspor, yakni untuk mengetahui faktor-faktor internal perusahaan berupa kekuatan apa saja yang sudah mereka miliki dan kelemahan apa yang masih harus dibenahi agar mampu melaksanakan ekspor. Selain itu juga harus diketahui bagaimana peluang dari perusahaan dan produk mereka untuk bias masuk ke pasar ekspor serta tantangan apa saja yang harus diatasi. Dari analisis SWOT ini, nantinya akan diketahui apa saja tindakan nyata (action plan) yang harus dilakukan untuk lebih meningkatkan kesiapan dan kemampuan mereka untuk ekspor

2) Business Plan yang disusun oleh peserta, berupa sebuah Rencana Bisnis Ekspor Produk X ke Negara Tujuan X pada tahun Z. Dengan demikian, sejak awal para peserta sudah menetapkan akan ke mana ekspor mereka tujukan. Business Plan ini akan menjadi alat ukur apakah dalam pelaksanaannya rencana tersebut tetap konsisten atau mengalami perubahanperubahan?

3) Sebagai hasil dari analisis SWOT, tindakan nyata yang akan mereka lakukan adalah berdasarkan prinsip SMART, yakni Specific, Measurable, Achievable, Rationable dan Time bound, sehingga terdapat skala prioritas dalam melakukan pembenahan, dengan melihat factor urgensi dan relevansi suatu masalah dalam menciptakan dorongan kesiapan perusahaan untuk merealisasi rencana ekspornya.

4) Alat yang juga digunakan adalah Progress Report dari setiap peserta per tahapan, sehingga akan diketahui apakah dari satu tahap ke tahap lain kondisi kesiapan ekspor peserta telah mengalami peningkatan, tetap sama saja atau malah mengalami kemunduran?

Berdasarkan instrument - instrumen tersebut, Coach melaksanakan pembinaannya secara sistematik dan mengarahkan pembenahan secara gradual.

\section{Bahasan}

Bagi Indonesia, globalisasi perdagangan seperti MEA misalnya, sebenarnya merupakan peluang yang baik untuk meningkatkan perekomian karena hambatan perdagangan akan cenderung berkurang bahkan menjadi tidak ada. Hal tersebut akan berdampak pada peningkatan ekspor yang pada akhirnya akan meningkatkan GDP Indonesia. Namun demikian, di balik peluang tentu akan selalu muncul tantangan bagi Indonesia, misalnya adalah masalah penguasaan teknologi informasi oleh para pelaku usaha golongan UKM. Padahal dalam era global saat ini, hampir semua kegiatan komunikasi telah menggunakan teknologi digital. Oleh karena itu diperlukan strategi tertentu untuk membantu para UKM ini agar terbiasa dan bias menggunakan TI untuk menelusuri, mengolah dan memanfaatkan TI dalam kegiatan ekspornya.

Menurut Ashar (2006) pada konteks pelaku usaha kecil, peran teknologi informasi sangat penting mengingat kompetitor atau pesaing UKM tidak hanya dari bisnis lokal atau regional tetapi telah melibatkan pelaku usaha bisnis berskala internasional. Selain itu, menurut Sudaryanto dkk., penggunaan teknologi informasi dan komunikasi bagi pelaku UKM dalam menggerakkan roda bisnis dapat memberikan fleksibilitas baik dalam produksi, menerima tawaran, dan mendukung transaksi cepat tanpa kertas. Pemanfaatan teknologi informasi dalam menjalankan bisnis atau sering dikenal dengan istilah e-commerce bagi perusahaan 
kecil dapat memberikan fleksibilitas dalam produksi.

Hal ini memungkinkan pengiriman ke pelanggan secara lebih cepat untuk produk perangkat lunak, mengirimkan dan menerima penawaran secara cepat dan hemat, serta mendukung transaksi cepat tanpa kertas. Pemanfaatan internet memungkinkan UKM melakukan pemasaran dengan tujuan pasar global, sehingga peluang menembus ekspor terbuka luas. Di samping itu biaya transaksi juga bisa diturunkan. Dengan demikian, dapat disimpulkan bahwa pemanfaatan TI bagi UKM menjadi penting dalam rangka peningkatan daya saing di pasar global. Salah satu titik fokus dalam pemberdayaan UKM dengan berbasis TI adalah peningkatan daya saing.

Di era persiangan sekarang ini, peran TI sangat menetukan dalam pemberdayaan UKM. Jjika suatu usaha tanpa ditopang oleh penggunaan teknologi informasi dan komunikasi sekarang ini, maka dapat dipastikan bahwa UKM akan sulit pengembangannya. Oleh karena itu, UKM Indonesia harus mempersiapkan diri untuk bersaing dalam pasar tunggal Asean tersebut karena Indonesia sebagai pasar terbesar, sudah pasti diperebutkan oleh seluruh pelaku usaha di kawasan ini.

Hambatan kolaborasi perlu diatasi. Misalnya, usaha mikro dan kecil sulit masuk ke ritel swalayan karena tidak sanggup menunggu pembayaran produk yang mundur 1-2 bulan. Promosi keunggulan kualitas produk UKM ke konsumen juga masih lemah. Padahal, promosi melalui TI, biayanya relatif terjangkau bahkan bisa gratis. Masalahnya, UKM nasional belum banyak "melek" TI. Program pengenalan manfaat TI pada pelaku UKM perlu didukung oleh lembaga pemerintah seperti Kementerian Komunikasi dan Informatika, P.T. Telkom, kementerian teknis seperti Kementerian Perdagangan (dalam hal ini PPEI dengan Program Pendampingan Ekspo), serta pemerintah daerah. Demikian juga perguruan tinggi. Oleh karena itu, diharapkan dengan pemberdayaan UKM dalam rangka pemanfaatan TI untuk pengembangan usaha dapat meningkatkan daya saing di era pasar global.

Secara umum, membaca posisi Indonesia di tengah-tengah MEA, sebenarnya kondisi Indonesia tidak mengkhawatirkan, bahkan dapat dikatakan bahwa peluang Indonesia untuk menarik keuntungan maksimal dari tergabungnya Indonesia ke dalam MEA sangatlah besar, sepanjang strategi yang diterapkan tepat dan secara efektif dijalankan. Salah satu sektor potensial yang perlu mendapat perhatian serius untuk terciptanya kondisi menguntungkan bagi Indonesia dalam MEA, adalah melalui upaya pengembangan UKM berbasis ekspor, karena pemberlakuan perdagangan bebas dalam MEA akan mencakup 12 sektor prioritas, dimana tujuh diantaranya merupakan sektor barang yang berasal dari sektor pertanian, otomotif, elektronik, perikanan, produk karet, tekstil dan produk kayu, dimana Indonesia memiliki sumberdaya alam yang cukup besar untuk memproduksi barang-barang dengan jenis itu. Hanya saja, karena faktor kualitas yang masih perlu dibenahi, maka Indonesia belum bisa menikmati keuntungan yang maksimal dari perdagangan di sektor tersebut. Berdasarkan data United Nations Conference on Trade and Development (UNCTAD), Indonesia hanya menempati urutan keempat dalam daftar negara eksportir barang terbesar di Asean, yang terdiri dari Singapura, Thailand, Malaysia, Indonesia dan Philipina (Gatra Edisi khusus, Desember 2015).

UKM yang menjadi tulang punggung perekonomian negara-negara Asean, khususnya di Indonesia, berdasarkan data dari Kementerian Perdagangan (2017) mencapai 99,9\% dari seluruh unit bisnis yang jumlahnya lebih dari 57 juta unit. Penyerapan tenaga kerjanya pun sangat tinggi, dimana dari 117,7 juta tenaga kerja, 96,99\% bekerja di sektor UKM. Jika dilihat dari sektor ekspor, nilai ekspor Indonesia yang berasal dari UKM masih sangat minim, yakni hanya $15,68 \%$ dari total ekspor non migas. Ini berarti ekspor dari usaha besar yang jumlahnya hanya $0,01 \%$ dari total unit usaha, nilai ekspor Indonesia mencapai $84,32 \%$. 
Jika data ini dibaca lebih teliti, berarti jika terhadap sektor UMKM ini mampu dilakukan pembinaan yang efektif, potensinya dalam meningkatkan ekspor Indonesia akan sangat dahsyat, baik jika dilihat dari besarnya prosentase jumlah unit usaha, maupun dari besarnya dukungan tenaga kerja yang mampu diserapnya. Karena itu, menjadi tugas besar bagi Bangsa Indonesia adalah bagaimana mencari strategi yang palin efektif pembinaan UKM tersebut. Itu berarti tugas bersama seluruh Bangsa Indonesia, yang harus dikerjakan secara bersama-sama, bukan parsial ataupun sektoral. Semua pihak harus terlibat dalam sebuah sistem pembinaan terintegrasi yang bekerja secara efektif di bidangnya masingmasing, guna menghasilkan sebuah keluaran akhir (outcome) yang diharapkan. Mimpi itu harus diwujudkan atas dasar kerja keras dan usaha bersama.

Kata koordinasi memang sangat mudah untuk diucapkan tapi terbukti teramat sulit untuk dilakukan. Hanya saja, jika Bangsa Indonesia sudah terpaku pada asumsi seperti itu, semua hal akan menjadi sia-sia dan akan selalu berujung pada kegagalan karena sudah diawali dengan rasa pesimis dan tidak percaya diri. Banyak hal bisa dilakukan meskipun diawali oleh sebuah tindakan yang mungkin berksala kecil. Salah satunya adalah dengan membangun sebuah sinergi dalam hal pembinaan sumberdaya UKM berbasis ekspor, dimana telah di sebutkan di atas, meskipun serapannya atas tenaga kerja sangat besar, tapi karena kondisi SDM UKM itu yang masih sangat memprihatinkan, maka daya dukungnya terhadap kinerja ekspor UKM masih sangat rendah.

Sebenarnya jika penempatan Coach ini didukung dengan system yang lebih jelas disertai Standard Operational Procedures (SOP) yang baik, mungkin hasilnya akan lebih baik. Hal ini mengingat dalam tahun anggaran 2017, peran dari Coach yang ditunjuk belum optimal, misalnya sebagai berikut:

1. Tidak ada Standard Operational Procedures (SOP) untuk tugas Coach
2. Tidak didukung anggaran untuk pelaksanaan tugas Coach, sehingga pelibatannya dalam aktivitas program, terutama untuk yang dilakukan di daerah tidak bias sepenuhnya.

3. Kurangnya dukungan manajemen, karena permintaan Coach agar PPEI mengirim surat resmi kepada Atdag dan ITPC meminta buyer list tidak mendapat tanggapan, sehingga Coach mencari sendiri informasi tersebut.

4. Buyer List yang dikirim oleh para Atdag dan ITPC banyak yang out-of-date, sehingga ketika peserta mencoba mengontak alamat-alamat yang diberikan, banyak yang tidak mendapat balasan, atau malah email yang dikirim mental kembali karena alamat itu salah.

5. Banyak Atdag dan ITPC yang dihubungi oleh Coach tapi tidak merespon dengan bak, sehingga daftar yang diminta tidak diberikan.

Berdasarkan kenyataan seperti ini, maka penunjukan seorang Widyaiswara menjadi Coach tidak bisa berjalan optimal, yang akibatnya hasil akhir dari Program Pendampingan juga menjadi belum sesuai dengan harapan. Padahal, sebagaimana telah disinggung pada bagian-bagian awal tulisan ini, peran seorang Coach hanya akan bisa maksimal dalam meningkatkan hasil akhir Program Pendampingan Ekspor, jika kondisikondisi berikut bisa terpenuhi:

1. Ada Standard Operational Procedures (SOP) yang jelas sehingga baik Coach maupun manajemen PPEI tahu harus bagaimana dan menjalankan peran masingmasing sebagai apa dalam program ini.

2. Pelibatan Coach dalam tahapan kegiatan program hendaknya penuh dan tidak sepotong-sepotong dengan alasan tidak ada anggarannya. Hal ini menjadi kendala bagi peserta yang membutuhkan bimbingan dan juga Coach yang ingin memonitor perkembangan kemajuan serta permasalahan yang mereka hadapi.

3. Ada dukungan penuh dari pihak manajemen, dalam hal ini pimpinan PPEI, agar para Atase dan ITPC mau mengirimkan 
buyer list yang dibutuhkan oleh peserta. Daftar tersebut hendaknya juga suatu daftar yang update, dalam arti valid dan akurat, sehingga jika para peserta mengirim email tidak mental kembali karena alamatnya salah. Hampir $80 \%$ data dari berbagai Negara yang dikirim oleh para Atdag dan ITPC ini tidak akurat.

4. Atdag dan ITPC diharapkan bisa menjalin kerjasama dengan Coach, sehingga pada sisi Negara tujuan ekspor para Atdag dan ITPC mengarahkan calon pembeli, sedangkan pada sisi peserta yang menjadi eksportir, Coah memiliki kewajiban untuk mengarahkan mereka. Dengan demikian kedua belah pihak (buyer dan Seller) mendapat arahan yang baik serta informasi yang lebih detail sebelum terjadinya transaksi ekspor.

\section{Simpulan}

\section{Simpulan}

Usaha Kecil dan Menengah (UKM) menjadi tulang punggung perekonomian negara-negara Asean, khususnya di Indonesia, berdasarkan data dari Kementerian Perdagangan (2017) jumlah UKM ini mencapai 99,9\% dari seluruh unit bisnis yang jumlahnya lebih dari 57 juta unit. Penyerapan tenaga kerjanya pun sangat tinggi, dimana dari 117,7 juta tenaga kerja, $96,99 \%$ bekerja di sektor UKM. Sebagian UKM malah sudah melakukan ekspor, namun jika dilihat dari sektor ini, nilai ekspor Indonesia yang berasal dari UKM masih sangat minim, yakni hanya $15,68 \%$ dari total ekspor non migas. Ini berarti ekspor Indonesia yang berasal dari usaha besar, meskipun jumlah mereka hanya $0,01 \%$ dari total unit usaha, pangsa ekspor mereka mencapai $84,32 \%$.

Jika data ini dibaca lebih teliti, berarti jika sektor UMKM ini dilakukan pembinaan yang efektif, potensinya dalam meningkatkan ekspor Indonesia akan sangat dahsyat, baik jika dilihat dari besarnya prosentase jumlah unit usaha, maupun dari besarnya dukungan tenaga kerja yang mampu diserapnya. Karena itu, menjadi tugas besar bagi Bangsa Indonesia adalah bagaimana mencari strategi yang palin efektif pembinaan UKM tersebut.
Itu berarti tugas bersama seluruh Bangsa Indonesia, yang harus dikerjakan secara bersama-sama, bukan parsial ataupun sektoral. Semua pihak harus terlibat dalam sebuah sistem pembinaan terintegrasi yang bekerja secara efektif di bidangnya masingmasing, guna menghasilkan sebuah keluaran akhir (outcome) yang diharapkan.

Balai Besar Pendidikan dan Pelatihan Ekspor Indonesia di bawah Direktorat Jenderal Pengembangan Ekspor Nasional, Kementerian Perdagangan, yang berdiri sejak tahun 1990 telah menyelenggarakan kegiatan pelatihan kepada kalangan usahawan kecil dan menengah baik yang sudah maupun yang baru ingin melakukan ekspor. Setiap tahunnya lembaga ini menyelenggarakan kegiatan pelatihan tidak kurang sebanyak 130 angkatan per tahun, dimana kegiatan tersebut diselenggarakan baik di Jakarta maupun di Pusat, baik langsung oleh PPEI sendiri, khususnya yang diselenggarakan di Jakarta, maupun bekerja sama dengan berbagai lembaga di daerah. Dengan demikian, hingga akhir tahun 2017 ini, setelah 27 tahun berdirinya, PPEI telah memberi pelatihan kepada UKM ekspor sebanyak 27 (tahun) x 130 (angkatan) x 30 (peserta per angkatan), yang berarti jumlahnya sudah mencapai 105.300 orang.

Pelaksanaan Program Pendampingan, hingga tahun 2016 memperlihatkan hasil yang belum menggembirakan, dimana dari sejumlah $20 \mathrm{~s} / \mathrm{d} 30$ peserta yang dibina intensif selama satu tahun penuh, dari masing-masing angkatan hanya beberapa orang saja yang berhasil menjadi eksportir pada akhir pelaksanaan program, hal mana antara lain disebabkan oleh tidak adanya pembina yang secara intesif melakukan monitoring perkembangan peserta, sehingga peserta mengikuti kegiatan tahap per tahap hanya berdasarkan jadual yang sudah disusun. Komunikasi antara peserta dengan Panitia kurang intesif, sehingga jika timbul permasalahan peserta tidak tahu harus mengadukannya kepada siapa.

Pada tahun anggaran 2017, yakni setelah 6 (enam) tahun pelaksanaan Export Coaching Program ini, barulah PPEI menerapkan suatu system baru dalam pembinaan terhadap peserta program ini, yakni dengan menunjuk 
Widyaiswara untuk menjadi Coach pada masing-masing angkatan. Adapun tugas khusus bagi para Coach ini adalah melakukan pembinaan intensif kepada peserta, menjalin komunikasi dengan stake holder seperti Atdag dan ITPC, juga menyelenggarakan konsultasi dengan para fasilitator praktisi PPEI jika peserta membutuhkan.

Sebagai hasil akhir dari penunjukan Coach ini, maka program yang dilaksanakan pada tahun 2017 tersebut memperlihatkan hasil yang lebih baik daripada tahun-tahun sebelumnya, yakni terjadi kenaikan jumlah peserta yang berhasil menjadi eksportir. Jika pada tahun-tahun sebelumnya jumlah yang berhasil hanya sekitar 3-4 orang peserta, maka di tahun 2017 jumlahnya mengalami kenaikan tipis, yakni sekitar 6-7 orang. Ini juga masih belum sesuai dengan target yang diharapkan. Ada banyak hal yang menjadi kendala dan harus terlebih dahulu dibenahi agar Program Pendampingan Ekspor ini bisa menghasilkan out put yang maksimal.

2. Saran

1. Perlu disusun Standard Operational Procedures (SOP) yang jelas sehingga baik Coach maupun manajemen PPEI tahu harus bagaimana dan menjalankan peran masing-masing sebagai apa dalam program ini.

2. Perlu peningkatan pelibatan Coach dalam tahapan kegiatan program dan tidak sepotong-sepotong, karena ini menjadi kendala bagi peserta yang membutuhkan bimbingan dan juga Coach yang ingin memonitor perkembangan kemajuan serta permasalahan yang mereka hadapi.

3. Perlu dukungan penuh pihak manajemen, dalam hal ini pimpinan PPEI, agar para Atase Perdagangan dan ITPC mau mengirimkan buyer list yang dibutuhkan oleh peserta. Daftar tersebut hendaknya update, dalam arti valid dan akurat, sehingga jika para peserta mengirim email tidak mental kembali karena alamatnya salah. Selama ini, hampir $80 \%$ data dari berbagai Negara yang dikirim oleh para Atdag dan ITPC ini tidak akurat.

4. Atdag dan ITPC diharapkan bisa menjalin kerjasama dengan Coach, sehingga pada sisi Negara tujuan ekspor para Atdag dan ITPC mengarahkan calon pembeli, sedangkan pada sisi peserta yang menjadi eksportir, Coah memiliki kewajiban untuk mengarahkan mereka. Dengan demikian kedua belah pihak (buyer dan Seller) mendapat arahan yang baik serta informasi yang lebih detail sebelum terjadinya transaksi ekspor. Tangerang, Januari 2020

\section{E. Daftar Pustaka}

Baso Saleh dan Yayat D. Hadiyat , Penggunaan Teknologi Informasi di Kalangan Pelaku Usaha Mikro Kecil Menengah di Daerah Perbatasan (Studi di Kabupaten Belu ProvinsiNusa Tenggara Timur), Jurnal Pekommas, Vol. 1 No. 2, Oktober 2016.

Yunanto, Ary, Analisis Posisi Strategis UKM Perlogaman di Kota Tegal, Dosen Fakultas Ekonomi Universitas Jenderal Soedirman, Purwokerto.

Jones, R. J., Woods, S. A. and Guillaume,Y.R. $F$. (2015), The effectiveness of workpla ce coaching: a meta-analysis of learning and performance outcomes fr om coaching Journal of Occupational and Organizational Psychology

Nanny Rodjinandari, Bambang Supriadi, Kompetensi Pendampingan Pemandu Wisata Lokal Sebagai Developer of People. Program Diploma Kepariwisataan Universitas Merdeka Malang1 Jl. Bandung No. 1 Malang. Jurnal PESONA ISSN Vol. 2 No. 01 Desember 2016

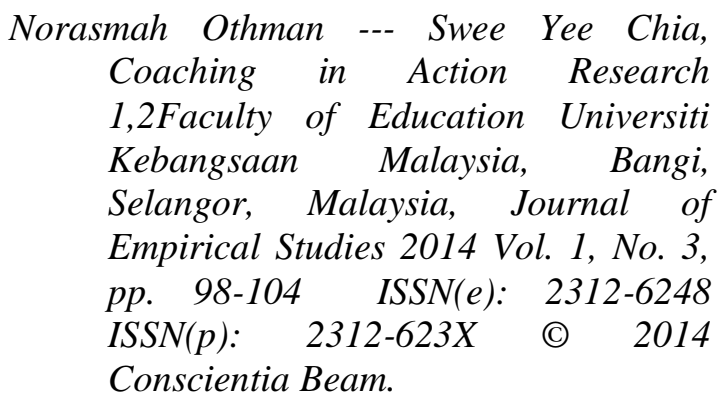

Novfitri Landong dan Namora Sihombing S.sos.M.si, Model Pendampingan UKM di Kota Tangerang Selatan, Penerbit PKN STAN Press. (C) 2018 
IA Volume 26, Nomor 1, Juli 2020

P-ISSN: 1411 - 545X | E ISSN: 2715-1662

Ninuk Purwaningsih, Titi Mawasti dan Yudhistira Saraswati, Analisis Kebutuhan Pendampingan dan Kompetensi Pendamping Pelaku Usaha Industri Jamu, Jurnal Jamu Indonesia, 2017

Robert Witherspoon dan Randall P. White, Executive Coaching A Continuum of Roles , Consulting Psychology Journal: Practice and Research Spring 1996 (1996)
Yeni Priatna Sari, Model Pendampingan UMKM Pengolahan Hasil Laut Dengan Metode Pendekatan Pendampingan Terintegrasi, Jurnal MONEX Volume 8 Nomor. 1 Januari 2019

TFO Canada, IETC Coaching System, A Training and Coaching Program For Indonesian Exporters, Presentation of June 7th, 2010 